\title{
Toll-like receptor agonist induced changes in clonal rat BRIN-BD11 $\beta$-cell insulin secretion and signal transduction
}

\author{
Aoife Kiely, Aisling Robinson, Neville H McClenaghan ${ }^{\mathbf{1}}$, Peter R Flatt ${ }^{\mathbf{1}}$ and Philip Newsholme \\ School of Biomolecular and Biomedical Sciences, Conway Institute and Health Sciences Centre, UCD Dublin, Belfield, Dublin 4, Ireland \\ ${ }^{1}$ School of Biomedical Sciences, University of Ulster, Coleraine BT52 1SA, Northern Ireland, UK \\ (Correspondence should be addressed to P Newsholme; Email: philip.newsholme@ucd.ie)
}

\begin{abstract}
Evidence for involvement of toll-like receptors (TLRs) (e.g. TLR4 and TLR2, whose agonists include lipopolysaccharides (LPS) and saturated fatty acids) in altered patterns of signalling in adipose, liver and muscle from animal models of insulin resistance and obesity has been published. We have now extended this area of research and have determined the effects of LPS on cell viability, insulin secretion, insulin signalling and metabolism in a clonal $\beta$-cell line. BRIN-BD11 $\beta$-cells were treated for $24 \mathrm{~h}$ with increasing concentrations of LPS. Chronic (24 h) and acute $(20 \mathrm{~min})$ insulin secretion, insulin content and parameters of cell metabolism and insulin signalling were determined. Incubation of BRIN-BD11 cells for $24 \mathrm{~h}$ in the presence of increasing concentrations of the TLR4 ligand LPS significantly decreased chronic $(24 \mathrm{~h})$ insulin secretion from
\end{abstract}

$1.09 \pm 0.19$ to $0.76 \pm 0.18 \mu \mathrm{g}$ insulin/mg protein in the presence of $100 \mathrm{ng} / \mathrm{ml}$ LPS $(P<0 \cdot 05)$. There was no change in acute $(20 \mathrm{~min})$ stimulated insulin secretion or insulin content. Cell metabolism was not changed. Insulin receptor- $\beta$ (IR $\beta)$ expression levels were increased significantly from $1 \pm 0.52$ to $8.6 \pm 1.83$ units $(P<0.01)$, whereas calcineurin activity and Akt phosphorylation were significantly $(P<0 \cdot 01$ and $P<0.05$ respectively) reduced in response to $24 \mathrm{~h}$ incubation in the presence of LPS. There was no change in IR substrate-1 protein expression or phosphorylation after $24 \mathrm{~h}$. Further incubation for $24 \mathrm{~h}$ in the absence of LPS resulted in the recovery of chronic insulin secretion. The negative $\beta$-cell effects of LPS may contribute to hyperglycaemia in vivo.

Journal of Endocrinology (2009) 202, 365-373

\section{Introduction}

Toll-like receptors (TLRs) are a family of evolutionarily conserved receptors primarily involved in regulation of the immune system by sensing a range of chemicals produced by pathogens such as bacteria and viruses and activating immune cell responses (O'Neill 2006). TLR signalling has a number of effects on the activities of antigen presenting cells, including production of inflammatory cytokines and up-regulation of MHC products. TLR expression has been demonstrated on cells such as macrophages and dendritic cells (Atkinson 2008).

However, the expression has also been reported on numerous other cells throughout the body, including those from various tissues and organs and some cell lines (Vives-Pi et al. 2003, Tsukumo et al. 2007). Indeed, TLR4, TLR2 and the leucine-rich repeat MD-2 proteins have been detected in islet cells, thus suggesting that $\beta$-cells express a functional lipopolysaccharide (LPS) receptor (Vives-Pi et al. 2003). Evidence for involvement of innate immune product receptors, e.g. TLRs, in insulin resistance has been recently published (Tsukumo et al. 2007). Notably type 2 diabetes has been associated with chronic low-grade inflammation
(Creely et al. 2007) in addition to the well-defined tissue insulin resistance (which is the result of changes in insulin receptor (IR) coupled signal transduction pathways in muscle, adipose tissue and liver, Tsukumo et al. 2007). As well as innate immune products such as LPS, adaptive immune factors such as pro-inflammatory cytokines (such as tumour necrosis factor- $\alpha$ (TNF- $\alpha$ ) and interleukin-1 $\beta$ (IL-1 $\beta)$ ) can alter patterns of insulin signalling in these target tissues, resulting in resistance to the action of insulin (Tilg \& Moschen 2008).

Recent work has implicated fatty acids as agonists for TLR 4 and TLR 2 and thus established a possible connection between altered patterns of insulin signalling in animal models of insulin resistance and obesity (Lee et al. 2003). In contrast to saturated fatty acids, polyunsaturated fatty acids inhibit this pathway (Poltorak et al. 1998, Lee et al. 2003, Tsukumo et al. 2007). Loss of function mutations in the TLR4 receptor had a beneficial effect on the insulin signalling pathways in adipose, muscle and liver tissues in mice and improved insulin action (Tsukumo et al. 2007). Human adipocytes were demonstrated to have inducible TLR 4 and TLR2 pathways further supporting the role that adipose tissue may play in the regulation of inflammation (Vitseva et al. 2008). 
Primary $\beta$-cells and some cell lines, such as HP62 and RINm5f, have been reported to express TLR 2 and TLR 4 (Vives-Pi et al. 2003); thus, we determined mRNA expression of the various TLRs in the rat $\beta$-cell line BRIN-BD11 and have determined the effects of LPS on $\beta$-cell insulin secretion and content, viability, metabolism and insulin signal transduction pathways.

While glucose and alanine are recognised as potent insulinotropic nutrients (Newsholme et al. 2006, McClenaghan 2007), glutamine is generally thought less important. However, glutamine metabolism in the $\beta$-cell may play multiple roles -1 ) production of intracellular glutamate and glutathione, which acutely stimulates insulin secretion (Brennan et al. 2003), 2) stimulation of acyl-CoA production, which would be important for the amplification of insulin secretion, 3) chronic release of glutamate from the cell, therefore, inhibiting insulin secretion via interaction with ionotrophic and metabotrophic glutamate receptors (Corless et al. 2006) and 4) up-regulation of calcineurin expression and activity, which may impact on pro-survival gene expression and NMDA receptor-dependent ion fluxes (Corless et al. 2006). Thus, a study, such as the one described here, of the effect of LPS on metabolism of insulinotrophic nutrients, should include determination of utilisation of glucose, alanine and glutamine.

BRIN-BD11 $\beta$-cells represent a useful model for such studies with stability in culture and well-characterised metabolic, signalling, insulin secretion and cell viability responses to glucose, amino acids and numerous other modulators of $\beta$-cell function (McClenaghan et al. 1996a,b, Chapman et al. 1999, McClenaghan \& Flatt 1999, Brennan et al. 2002, 2003), and the present data extend characterisation of these cells and understanding of TLRs in the regulation of insulin secretion and signal transduction.

Table 1 PCR primer sequences for toll-like receptors (TLRs) in the rat

\section{Materials and Methods}

\section{Cell culture}

BRIN-BD11 cells were cultured in RPMI 1640 media supplemented with $10 \%(\mathrm{v} / \mathrm{v})$ foetal bovine serum and $0 \cdot 1 \%$ antibiotics $(100 \mathrm{U} / \mathrm{ml}$ penicillin and $0.1 \mathrm{mg} / \mathrm{ml}$ streptomycin). Cells $\left(1.5 \times 10^{5}\right)$ were seeded in 24 -well plates containing $1 \mathrm{ml}$ media or $1.5 \times 10^{6}$ cells were seeded in 6-well plates containing $5 \mathrm{ml}$ media and allowed to adhere overnight, before treatment in the presence or absence of various concentrations of LPS (LPS from Escherichia coli was sourced from Autogen Bioclear, product no. tlrl-eblps). A stock solution of LPS $(5 \mathrm{mg} / \mathrm{ml})$ was prepared utilising sterile PBS. Subsequent dilutions were prepared with standard RPMI 1640 culture media. The cells were maintained at $37^{\circ} \mathrm{C}$ in a humidified atmosphere of $5 \% \mathrm{CO}_{2}$ and $95 \%$ air using a Forma Scientific incubator.

\section{RT-PCR}

Total RNA was isolated using TRIzol reagent (Invitrogen), according to the manufacturer's recommendation. The Superscript Preamplification System II (Invitrogen) and oligo(dT) primer were used for the synthesis of cDNA. Gene-specific primers (Table 1) were used for the PCR, which utilised Taq polymerase (Applied Biosystems). The obtained PCR products were separated by $\mathrm{EtBr}$ supplemented agarose gel electrophoresis and visualised with u.v. light. PCR products were excised from the gel, purified and commercially sequenced (MWG Biotech, Edersberg, Germany). In all cases, the sequence returned matched the expected TLR sequence within 98\% and in most cases, $100 \%$.

\section{Sequence}

TLR1

TLR2

TLR3

TLR4

TLR5

TLR6

TLR7

TLR8

TLR9

TLR10
FWD: TTGTCCCACAATGAGTTAAGG REV: ATTCGCCCTTGGTCTTCTTTT FWD: GGAGACTCTGGAAGCAGGTG REV: ATCCTGCTCGCTGTAGGAAA FWD: GCCTTAATGAAATTGAGCAAGAA REV: CTGGGAACCAAAGTGAAGGACT FWD: CATGGCATTGTTCCTTTCCT REV: GTCTCCACAGCCACCAGATT FWD: GAAGGCTGTGAATCTCGTTGG REV: CTGCCCAACCTCAGGATCTTA FWD: GGCTGGCCTGACTCTTACAG REV: TCTGGATGAAGTGTGGAGAC FWD: TTTCCCAGAGCATACAGCTCAG REV: CACTCAAGGACAGAACTGCTGC FWD: CAGAGCATAAACCAGAGCAAGAA REV: CTCATCCATTAGCCTCTGCAAG FWD: TGCAGGAGCTGAACATGAAC REV: TGACGAACATCTCTGGCTTG FWD: CAACTTTGTGCAGAATGGGTG REV: AGGGAACTTGGTAGGAACACAGT
Assession no.

Length

Hubert et al. (2004) (unknown)

NM_198769

XM_579729

NM_019178

XM_223016

201

NM_207604

466

XM_228909

216

NM_133212

110

NM_198131

XM_223422 


\section{Cell viability}

Cell viability was determined by WST-1 analysis, a successor of the popular MTTassay, which has the benefit of being cheaper, faster and more convenient to use (Takamatsu 1998). Cell viability was determined using the cell proliferation reagent WST-1, a tetrazolium salt that is cleaved by mitochondrial dehydrogenases in viable cells. Briefly, $100 \mu \mathrm{l}$ cell suspension (containing $2 \times 10^{4}$ cells) was plated in each well of a 96-well plate. After overnight culture, to allow reattachment, the cells were incubated in the absence or presence of various concentrations of LPS or various concentrations of glutamine for $24 \mathrm{~h}$. At the end of each experiment, the cell proliferation reagent WST-1 $(10 \mu \mathrm{l})$ was added to each well, and the cells were incubated at $37^{\circ} \mathrm{C}$ for either 0.5 or $1.5 \mathrm{~h} . A_{450 \mathrm{~nm}}$ was measured using a kinetic plate reader (Spectramax Plus; Molecular Devices, Sunnyvalle, CA, USA).

\section{Determination of metabolites}

D-glucose, L-glutamine, L-glutamate and L-lactate concentrations were determined using the YSI 7100 Multiparameter Bioanalytical System. An aliquot of supernatant (either culture medium or Krebs-Ringer bicarbonate buffer) was removed from the tissue culture plate or flask, centrifuged for $5 \mathrm{~min}$ at $400 \mathrm{~g}$ and analysed. The linear range of each assay run was as follows: D-glucose (dynamic range of 0.05-25.0 g/l); L-lactate $(0 \cdot 05-2 \cdot 7 \mathrm{~g} / \mathrm{l}) ; \mathrm{L}-$ glutamate $(15-1460 \mathrm{mg} / \mathrm{l})$; and L-glutamine (30-1169 mg/l). Nitric oxide concentrations in the culture media were determined using the Griess Reagent System (Promega, Medical Supply Co). The rate of nitrite production was expressed as $\mu \mathrm{mol} / \mathrm{mg}$ protein per $24 \mathrm{~h}$.

\section{Insulin secretion}

Cells were treated for $24 \mathrm{~h}$ in the absence or presence of various concentrations of LPS. The media was removed and stored for later insulin analysis. The cells were then washed with PBS, and acute insulin secretion was initiated after incubating the cells for $40 \mathrm{~min}$ in $\mathrm{KRB} \mathrm{pH} 7 \cdot 4$ containing $1.1 \mathrm{mM}$ glucose (in the absence of LPS), by subsequent stimulation for $20 \mathrm{~min}$ in $\mathrm{KRB} \mathrm{pH} 7 \cdot 4$ containing $16.7 \mathrm{mM}$ glucose plus $10 \mathrm{mM}$ alanine (in the absence of LPS). Insulin secretion (acute and chronic) was determined using a Mercodia Ultrasensitive Rat Insulin ELISA kit (Uppsala, Sweden).

\section{Insulin content}

After 24-h incubation, the media was removed and cells were washed with sterile PBS. Intracellular insulin was extracted overnight at $4{ }^{\circ} \mathrm{C}$ from the monolayer cells with $1 \mathrm{ml} /$ well of acid ethanol $(1.5 \% \mathrm{HCl}$ in $70 \%$ ethanol, Hamaguchi et al. 2003).

\section{Western blot analysis}

Protein was extracted using the RIPA buffer supplemented with protease inhibitor cocktail (Sigma P8340), phenylmethylsulphonyl fluoride $(1 \mathrm{mM}), \mathrm{NaF}(1 \mathrm{mM})$, microcysteine $(2 \mathrm{mM}), \mathrm{Na}_{3} \mathrm{VO}_{4}(100 \mathrm{mM})$ and benzamidine $(10 \mathrm{mM})$. Protein concentration was determined with the BCA protein assay kit (Pierce products supplied by Fisher Scientific, Dublin, Ireland) and equivalent amounts of protein were subjected to SDS-PAGE and electrophoretically transferred onto a nitrocellulose sheet. The sheet was blocked in $5 \%$ milk protein and incubated with polyclonal anti-IR substrate-1 (IRS1), p-IRS1, Akt, p-Akt (Akt/Thr ${ }^{308}$ phosphorylation, a marker of Akt activation, Barry et al. 2009), IRb, p42/44 or p-p42/44 (Santa Cruz, Heidelburg, Germany). The blots were washed and probed with HRP and visualised with SuperSignal West Pico Chemiluminescent Substrate (Pierce). GAPDH was used as a loading control.

\section{Protein determination}

Cell protein was extracted using RIPA lysis reagent containing $1 \times$ Halt Protease Inhibitor Cocktail (Thermo Scientific products supplied by Fisher Scientific, Dublin, Ireland). Cellular protein was determined using a BCA protein assay kit (Pierce, kit no. 23225), which utilises a modification of the biuret reaction.

\section{Calcineurin activity}

Calcineurin activity was determined by the Calcineurin Assay Kit (Calbiochem) following incubation of the cells for $24 \mathrm{~h}$ in the presence of LPS and in the presence or absence of either 2 or $10 \mathrm{mM}$ L-glutamine.

\section{Statistical analysis}

The results are presented as mean \pm s.E.M. Groups of data were compared using a Student's unpaired $t$-test or ANOVA where appropriate. Differences were considered significant at a $P$ value of $<0.05$ (indicated by $\star$ ) or 0.01 (indicated by $\star \star$ ).

\section{Results}

Receptor expression

The mRNA expression of nine members of the TLR family was detected by RT-PCR in the BRIN-BD11 pancreatic $\beta$-cell line, including TLR4 and TLR2 (Fig. 1). PCR

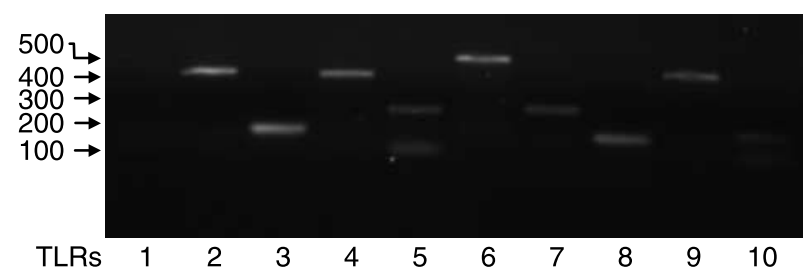

Figure 1 PCR analysis for TLR isoforms in BRIN-BD11 cells. The RNA was isolated as described in the Materials and Methods; CDNA was synthesized and RT-PCR was performed using specific primers for TLRs 1-10. Bp sizes are indicated (from Promega markers). Results are from a representative experiment. 


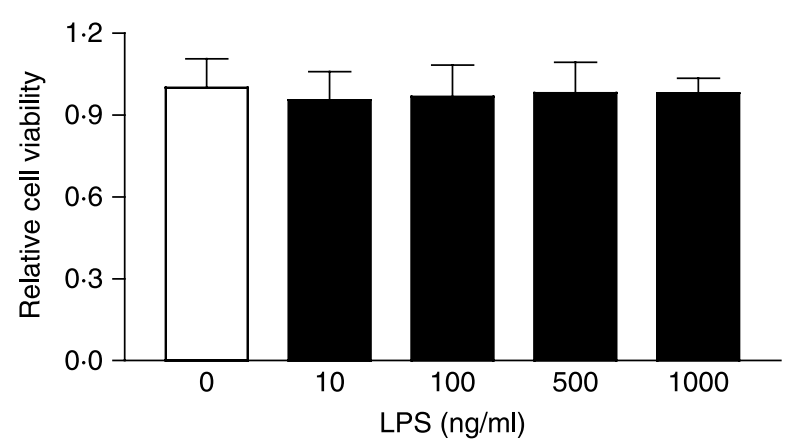

Figure 2 BRIN-BD11 cells were incubated for $24 \mathrm{~h}$ in the presence of increasing concentrations of LPS. Relative cell viability was determined by the WST-1 assay. There was no loss of cell viability after incubation of BRIN-BD11 cells for $24 \mathrm{~h}$ in the presence of up to $1000 \mathrm{ng} / \mathrm{ml}$ LPS. Results are expressed as mean \pm S.E.M., $n=3$.

products were excised from the gel, purified and commercially sequenced (MWG Biotech). In all cases, the sequence returned matched the expected TLR sequence within $98 \%$ and in most cases, $100 \%$. We were unable to explain the presence of a small PCR product in lane 5 .
Cell viability, insulin content and insulin secretion

Cell viability as determined by WST-1 analysis was not altered following $24 \mathrm{~h}$ exposure to various concentrations of LPS, $10-1000 \mathrm{ng} / \mathrm{ml}$ (Fig. 2). As WST-1 absorbance is proportional to the activity of mitochondrial dehydrogenases, our results indicate that LPS exposure did not result in an increase (or indeed decrease) in mitochondrial metabolism; thus, did not alter mitochondrial oxidative phosphorylation.

A significant $(P<0 \cdot 05)$ reduction in chronic $(24 \mathrm{~h})$ insulin secretion was provoked by chronic exposure to the TLR 4 agonist LPS (24 h, Fig. 3A), but acute insulin secretion (20 min stimulation), tested after $24 \mathrm{~h}$ exposure to LPS, was not altered (Fig. 3B). BRIN-BD11 insulin content, determined after $24 \mathrm{~h}$ exposure to $10-1000 \mathrm{ng} / \mathrm{ml} \mathrm{LPS}$, was not altered (Fig. 3C). Incubation of treated cells for another $24 \mathrm{~h}$, in the absence of LPS, demonstrated a recovery of chronic (24 h) insulin secretion (Fig. 3D). The higher levels of insulin secretion determined after $24 \mathrm{~h}$, as described in Fig. 3D compared with Fig. 3A, may represent a cell culture-dependent elevation in chronic insulin secretion, related to the time spent in culture.
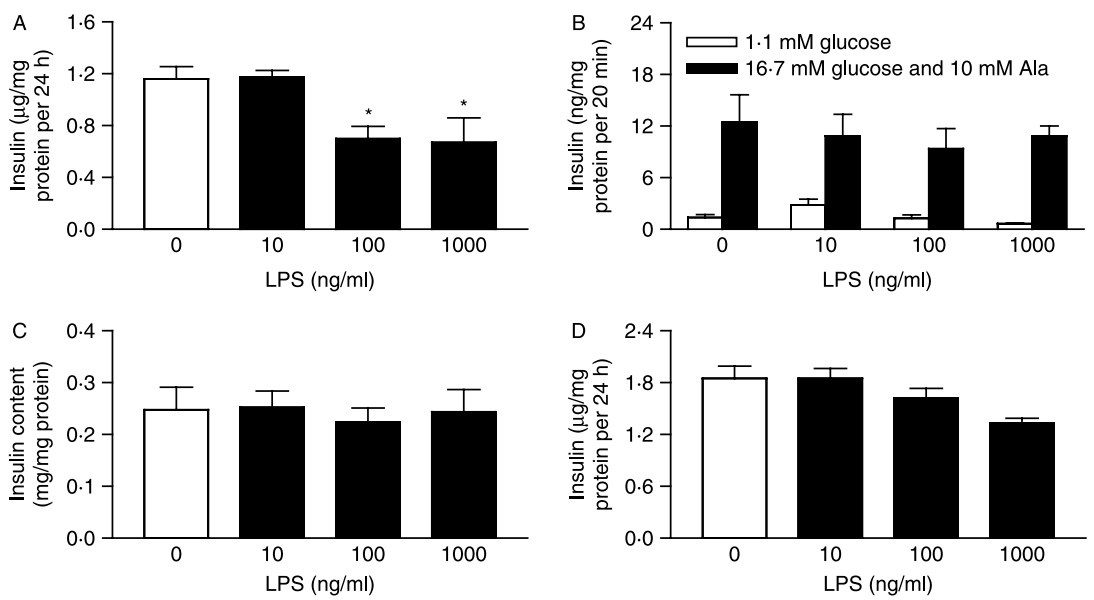

Figure 3 BRIN-BD11 cells were incubated for $24 \mathrm{~h}$ in the presence of increasing concentrations of LPS. In A, the media was removed and insulin concentration was determined by ELISA (Mercodia). Chronic insulin secretion ( $24 \mathrm{~h})$ was significantly $(P<0 \cdot 05)$ reduced after culture in the presence of 100 or $1000 \mathrm{ng} / \mathrm{ml}$ LPS. Results are expressed as mean \pm S.E.M., $n=3$ in duplicate. In B, after the media was removed, cells were incubated in Krebs buffer supplemented with $1.1 \mathrm{mM}$ glucose for $40 \mathrm{~min}$ (in the absence of LPS) before washing, and then were subjected to 20 min exposure to Krebs buffer supplemented with $1.1 \mathrm{mM}$ glucose (in the absence of LPS) or $16.7 \mathrm{mM}$ glucose plus $10 \mathrm{mM}$ alanine (in the absence of LPS). Acute nutrient-stimulated insulin secretion was not altered following $24 \mathrm{~h}$ incubation in the presence of LPS up to $1000 \mathrm{ng} / \mathrm{ml}$; insulin was determined by ELISA (Mercodia). Results are expressed as mean \pm S.E.M., $n=3$. In C, the BRIN-BD11 cells were incubated for $24 \mathrm{~h}$ in the presence of increasing concentrations of LPS. Intracellular insulin was extracted using acid-ethanol and concentration determined by ELISA (Mercodia). There was no change in insulin content after $24 \mathrm{~h}$ in the presence of increasing concentrations of LPS. Results are expressed as mean \pm S.E.M., $n=3$. In D, the BRIN-BD11 cells were incubated for $24 \mathrm{~h}$ in the presence of increasing concentrations of LPS, before washing with PBS, and incubated for another $24 \mathrm{~h}$ in the presence of RPMI 1640 media after which the insulin secretion was determined. Results are expressed as mean \pm s.E.M., $n=3$. 


\section{Nutrient consumption and product formation}

There was no change in glucose, alanine or glutamine consumption (three key nutrients for pancreatic $\beta$-cells, Dixon et al. 2003) or lactate, glutamate or nitrite production after $24 \mathrm{~h}$ incubation in the presence of $10-1000 \mathrm{ng} / \mathrm{ml}$ LPS (results not shown), which indicated that cell metabolism was not altered by TLR signalling thus metabolic stimulus secretion coupling most likely remained intact.

\section{Glutamine protection from LPS-induced inhibition of insulin secretion}

After $24 \mathrm{~h}$ incubation in the presence of $1000 \mathrm{ng} / \mathrm{ml}$ LPS and $2 \mathrm{mM}$ glutamine (standard tissue culture concentration), there was a significant $(P<0 \cdot 05)$ reduction in chronic insulin secretion (Fig. 4). However, the addition of $10 \mathrm{mM}$ glutamine attenuated LPS-induced inhibition of insulin secretion (Fig. 4).

\section{Calcineurin activity}

Calcineurin activity determined after BRIN-BD11 cells were incubated for $24 \mathrm{~h}$ in the presence of $2 \mathrm{mM}$ glutamine was significantly $(P<0 \cdot 01)$ reduced (by $42 \%)$ after incubation for $24 \mathrm{~h}$ in the presence of $1000 \mathrm{ng} / \mathrm{ml}$ LPS. Calcineurin activity was not elevated by the addition of $10 \mathrm{mM}$ L-glutamine, a concentration that has previously been shown to promote calcineurin activity in tissue culture conditions (Corless et al. 2006; Fig. 5).

\section{Insulin signalling}

LPS significantly $(P<0 \cdot 01)$ increased IR $\beta$ expression at 100 and $1000 \mathrm{ng} / \mathrm{ml}$ over a $24 \mathrm{~h}$ incubation period (Fig. 6). By contrast, exposure to LPS resulted in a significant

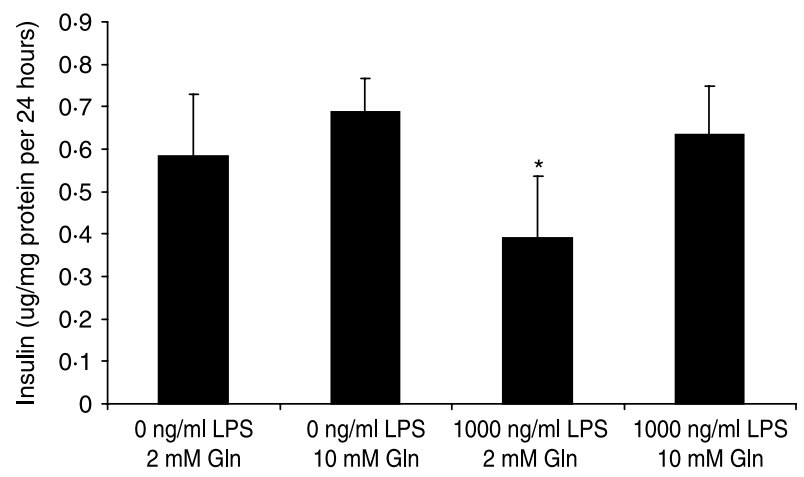

Figure 4 BRIN-BD11 cells were incubated for $24 \mathrm{~h}$ in the presence or absence of $1000 \mathrm{ng} / \mathrm{ml}$ LPS in the presence of either 2 or $10 \mathrm{mM}$ glutamine. Media was removed and analysed for insulin concentration by ELISA (Mercodia). LPS at $1000 \mathrm{ng} / \mathrm{ml}$ significantly reduced $(P<0 \cdot 05)$ chronic $(24 \mathrm{~h})$ insulin secretion when BRIN-BD11 cells were incubated at $2 \mathrm{mM}$ glutamine. Results are expressed as mean \pm s.E.M., $n=3$ in duplicate.

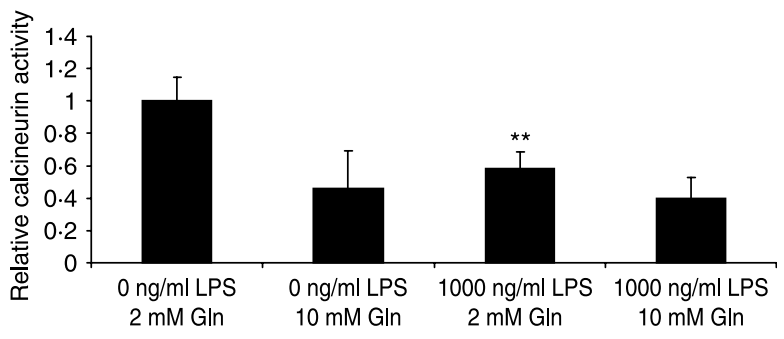

Figure 5 BRIN-BD11 cells were incubated for $24 \mathrm{~h}$ in the presence or absence of $1000 \mathrm{ng} / \mathrm{ml}$ LPS in the presence of either 2 or $10 \mathrm{mM}$ glutamine, and calcineurin activity was subsequently determined. Calcineurin activity was significantly reduced $(P<0 \cdot 1)$ in the presence of $1000 \mathrm{ng} / \mathrm{ml}$ LPS and $2 \mathrm{mM}$ glutamine. Results are expressed as mean \pm S.E.M., $n=3$ in duplicate.

reduction in the level of Akt/Thr ${ }^{308}$ phosphorylation (activated Akt, $P<0 \cdot 05$; Fig. 7). However, phosphorylated IRS1 and phosphorylated p 42/44 levels were not significantly altered by LPS (Fig. 8).

\section{Discussion}

TLRs play a critical role in the activation of appropriate innate immune responses in mammals by recognising conserved pathogen-associated molecules such as LPS (Tsukumo et al. 2007). Indeed, 13 members of the TLR family have been identified in mammals and we have determined nine members in the rat $\beta$-cell line BRINBD11. While TLR2 is involved in the responses to a range of constituents of the cell walls of pathogens, TLR 4 is a subclass that can be ligated by LPS and by non-bacterial agonists, such as saturated fatty acids (Tsukumo et al. 2007). Activation of TLR4 signalling at the cell surface induces activation of specific intracellular inflammatory pathways, which sensitive cells and tissues are related to the induction of insulin resistance due to suppression of insulin signalling pathways. Interestingly, TLR2 maps to the same chromosome region as the NOD mouse diabetes susceptibility gene $I d d 17$ (Podolin et al. 1997), and the gene encoding TLR4 maps to chromosome 9q33 (Rock et al. 1998), which has also been mapped to an unnamed type 1 diabetes locus (Concannon et al. 2005). In a recent study, mice with a loss-of-function mutation in TLR4 $(\mathrm{C} 3 \mathrm{H} / \mathrm{HeJ})$ were protected against the development of diet-induced obesity and insulin resistance and that, in isolated muscles from $\mathrm{C} 3 \mathrm{H} / \mathrm{HeJ}$ mice, there was a protection from saturated fatty acid-induced insulin resistance (Tsukumo et al. 2007). Saturated fatty acids are known to suppress insulin signalling in muscle (Pan et al. 1997).

High fat feeding has been reported to increase plasma LPS levels, while LPS infusion in normal fed mice caused a metabolic response similar to that of the high-fat fed mice (Cani et al. 2007). Additionally, endogenous LPS is continuously produced from the gut due to the degradation of intestinal flora (Drewe et al. 2001). LPS has been 


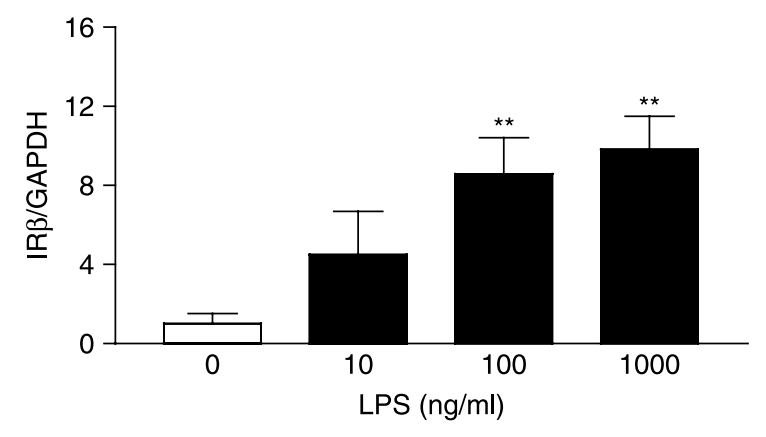

$\operatorname{IR} \beta$

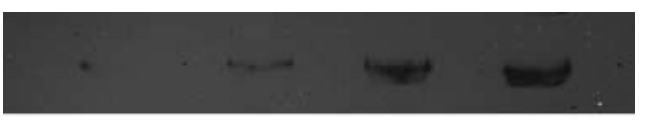

GAPDH

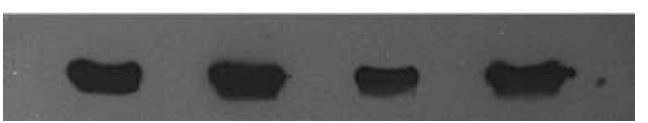

Figure 6 BRIN-BD11 cells were incubated for $24 \mathrm{~h}$ in increasing concentrations of LPS. Western blot analysis was performed to determine the levels of IR $\beta$ protein expression; GAPDH was used as an expression control. There was a significant increase $(P<0 \cdot 01)$ in IR $\beta$ expression levels after $24 \mathrm{~h}$ incubation in the presence of LPS. Results are expressed as mean \pm s.E.M., $n=3$.

reported to lower blood glucose levels in both humans and animals (Oguri et al. 2002), via enhanced systemic consumption of glucose, depletion of glucose from the liver and muscle and impaired hepatic gluconeogenesis (Sherry et al. 2007). There are no studies to date that have addressed the effects of LPS on in vitro cell culture insulin secretion, but one in vivo study has demonstrated positive correlation between serum LPS and fasting insulin levels in humans (Creely et al. 2007). We have now demonstrated that LPS can reduce chronic $(24 \mathrm{~h})$ insulin secretion in cell culture conditions, but subsequent acute (20 min) glucose plus amino acid-stimulated insulin secretion was not altered, nor was BRIN-BD11 insulin content. Nutrient consumption (glucose and glutamine) and metabolite production (glutamate, lactate and nitrite) were unaffected by LPS in the concentration range used in this study. This indicates that cell metabolism was not altered by TLR signalling, thus, metabolic stimulus secretion factor generation was not impaired.

Post-transplant diabetes mellitus has been linked to inhibition of calcineurin by immune system suppressors such as cyclosporin A (Heit et al. 2006) suggesting impairment of $\beta$-cell function by the drug. Calcineurin negatively regulates TLR-mediated activation pathways in macrophages by inhibiting the adaptor proteins MyD88, TRIF, TLR2 and TLR4 (Kang et al. 2007). Calcineurin inhibitors have been shown to induce $\mathrm{NF \kappa B}$ activation in macrophages (Kang et al. 2007). The fact that calcineurin interacts with MyD88, TRIF, TLR2 and TLR4 was established by co-immunoprecipitation; however, the cause/effect relationship was not (Kang et al. 2007). We have demonstrated that calcineurin activity in BRIN-BD11 cells incubated for $24 \mathrm{~h}$ in the presence of LPS was reduction by $42 \%$. Indeed, calcineurin may be an important signalling component in $\beta$-cells as it is $\mathrm{Ca}^{2+}$ sensitive (Lawrence et al. 2008) and will dephosphorylate important transcription factors such as NFAT (Heit et al. 2006). It has also been demonstrated that $10 \mathrm{mM}$ Gln significantly increased calcineurin activity compared with $1 \mathrm{mM}$ Gln in BRIN-BD11 $\beta$-cells (Corless et al. 2006). In the study reported here, incubation of BRIN-BD11 cells in $10 \mathrm{mM} \mathrm{L-glutamine}$ attenuated LPS suppressed chronic insulin secretion, but this effect was not due to restored calcineurin activity. There was no increase of NO production (determined by nitrite analysis) in BRIN-BD11 cells incubated with LPS. i.p. injection of LPS $(10 \mathrm{mg} / \mathrm{kg})$ for $48 \mathrm{~h}$ was recently demonstrated to significantly increase enterocyte apoptosis in rat intestines in vivo, and this was significantly attenuated by dietary glutamine (Kessel et al. 2008). Glutamine has also been implicated as a treatment for LPS-induced sceptic shock by reducing the expression of HSP70 and plasma concentrations of TNF- $\alpha$ and IL- 6 in a rodent population ( Jing et al. 2007).

Following insulin binding, the IR is autophosphorylated. The activated IR then phosphorylates IRS1 and related substrates. Activated IRS1 can activate PI3-kinase, which in turn activates PI3 kinase-dependent serine/threonine kinases and then $\mathrm{PKB} / \mathrm{Akt}$. PKB/Akt is involved in the regulation of multiple signalling processes, including regulation of glucose
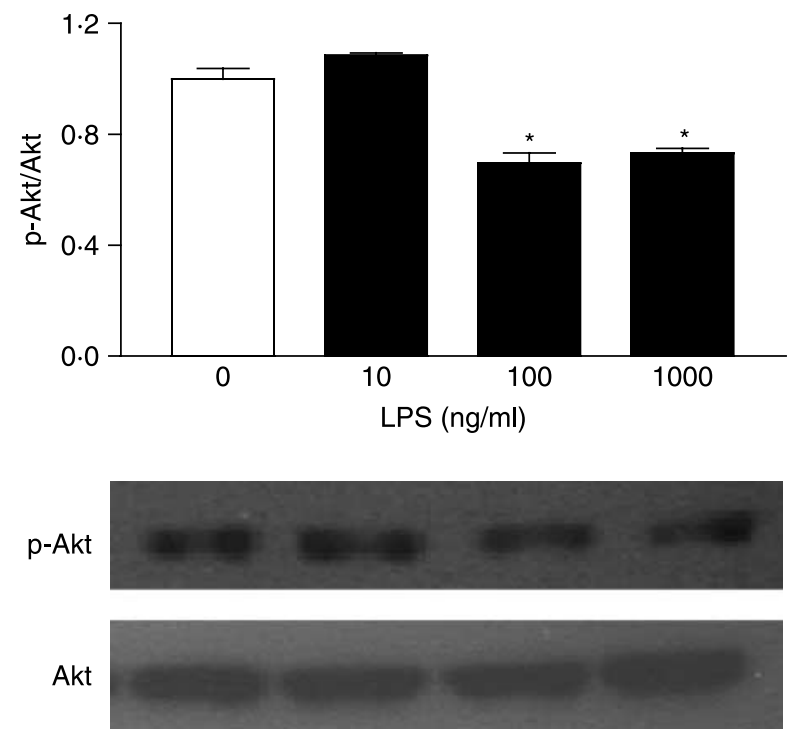

Figure 7 BRIN-BD11 cells were incubated for $24 \mathrm{~h}$ in increasing concentrations of LPS. Western blot analysis was performed to determine levels of Akt and $\mathrm{p}$-Akt $\left(\mathrm{Thr}^{308}\right)$ protein expression. There was a small but significant $(P<0 \cdot 05)$ reduction in phosphorylated Akt levels after $24 \mathrm{~h}$ incubation in the presence of $100-1000 \mathrm{ng} / \mathrm{ml}$ LPS. Results are expressed as mean \pm S.E.M., $n=3$. 

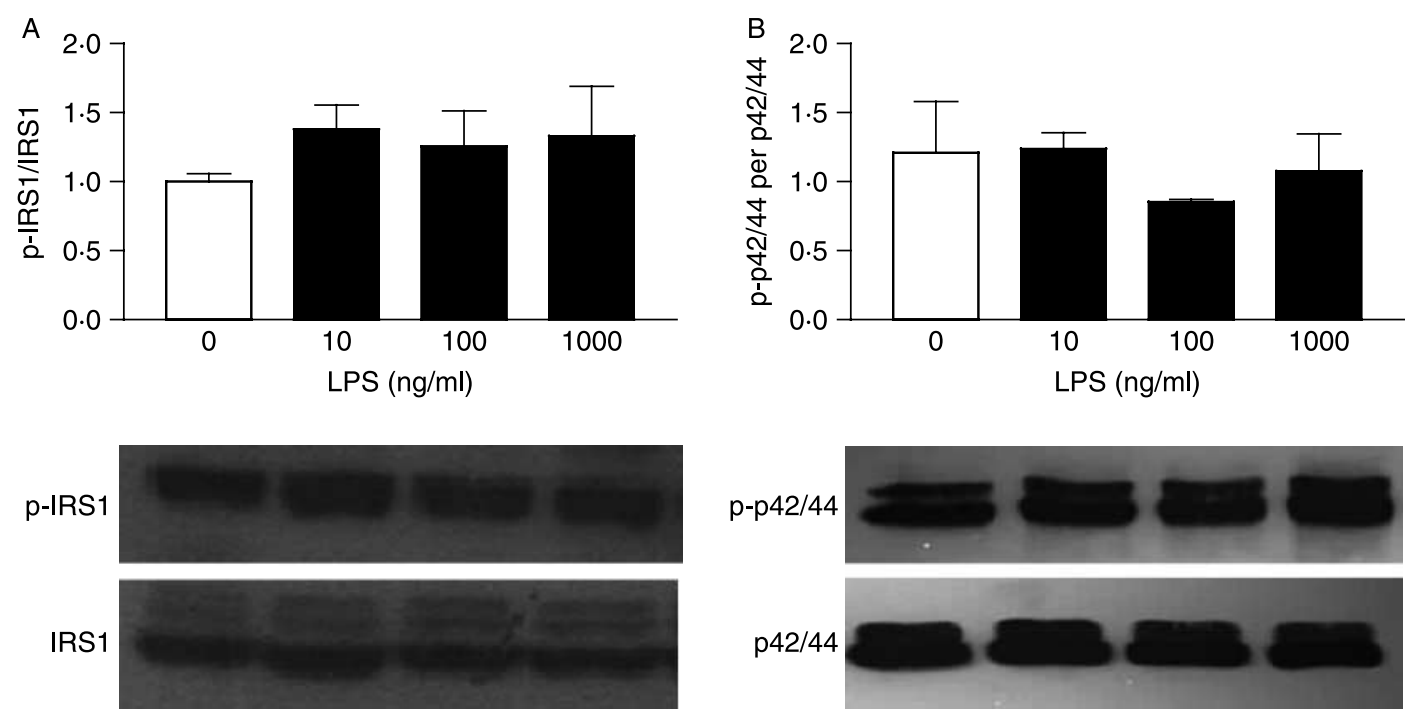

Figure 8 BRIN-BD11 cells were incubated for $24 \mathrm{~h}$ in increasing concentrations of LPS. Western blot analysis was performed to determine expression and phosphorylation levels of IRS1 expression and phosphorylation levels of $\mathrm{p} 42 / 44$. There was no change in IRS1 or p42/44 protein expression or phosphorylation levels after $24 \mathrm{~h}$ incubation in the presence of LPS. Results are expressed as mean \pm s.E.M., $n=3$.

metabolism, cell survival and proliferation and gene transcription. $\mathrm{PKB} / \mathrm{Akt}$ is a pro-survival intracellular signalling molecule, known to be activated in the pancreatic $\beta$-cell by a number of different growth factors (Fiaschi-Taesch et al. 2007). PKB/Akt is activated by phosphorylation on $\mathrm{Thr}^{308}$ and $\mathrm{Ser}^{473}$. Activation of the PI3K/Akt pathway has been shown to be associated with increased cell survival and proliferation in rodent cells in vitro (Dickson \& Rhodes 2004). It is accepted that elevated glucose metabolism can stimulate insulin secretion in a process involving oxidative glucose metabolism, an elevation in the ATP/ADP ratio, closure of the $\mathrm{K}_{\mathrm{ATP}}^{+}$channels, membrane depolarisation and calcium influx, which results in insulin release (McClenaghan 2007). More recently, the involvement of the $\beta$-cell IR and its signalling pathway in secretion has been reported (Accili 2004). Site-specific inhibition of either the IR or IRS1 in $\beta$-cells has been shown to impair glucose sensing (Kulkarni et al. 1999a,b), implying that insulin resistance at the level of the insulin signalling cascade in the $\beta$-cell may play a role in the pathogenesis of type 2 diabetes.

Indeed, the observed decrease in phosphorylated (activated) Akt reported in this study may account for the inhibition of chronic $(24 \mathrm{~h})$ insulin secretion in culture conditions, while acute $(20 \mathrm{~min})$ stimulation was unaffected, probably due to the fact that acute stimulation is almost entirely dependent on metabolic stimulus secretion coupling. Conversely, overexpression of a constitutively active Akt in the mouse $\beta$-cell increased $\beta$-cell size and number, and total islet mass (Bernal-Mizrachi et al. 2001, Tuttle et al. 2001). A recently published study investigated insulin signalling in the livers of $\mathrm{C} 3 \mathrm{H} / \mathrm{HeJ}$ mice (which have a loss-of-function mutation in TLR4) and control mice (Tsukumo et al. 2007). They detected a 50\% reduction in insulin-induced IRS1 tyrosine phosphorylation accompanied by a 30\% reduction in IRS1 protein content and a 70\% reduction in Akt phosphorylation in the livers of control mice fed a high-fat diet but not in $\mathrm{C} 3 \mathrm{H} / \mathrm{HeJ}$ mice fed the same diet. While we determined the effect on insulin signalling in response to LPS only, in $\beta$-cells, both LPS and saturated fatty acids may exert their effects through the TLR4 protein in vivo. Furthermore, we were able to demonstrate an increase in IR $\beta$ protein level but a reduction in activated Akt in response to LPS, but IRS1 and p42/44 phosphorylation (and therefore activation) levels were unaltered.

In conclusion, TLR agonists such as LPS may suppress insulin secretion from the $\beta$-cell, which may compound the known detrimental effects of insulin resistance in vivo.

\section{Declaration of interest}

There is no conflict of interest in relation to any of the authors of this paper and publication in the Journal of Endocrinology.

\section{Funding}

This work was supported by the Health Research Board of Ireland and UCD Dublin.

\section{Acknowledgements}

We thank Dr Derek Brazil, UCD Dublin, for help and advice with western blots. 


\section{References}

Accili D 2004 Lilly lecture 2003: the struggle for mastery in insulin action: from triumvirate to republic. Diabetes 53 1633-1642.

Atkinson TJ 2008 Toll-like receptors, transduction-effector pathways and disease diversity: evidence of an immunobiological paradigm explaining all human illness? International Reviews of Immunology 27 255-281.

Barry EF, Felquer FA, Powell JA, Biggs L, Stomski FC, Urbani A, Hoffmann P, Wilce MC, Grimbaldeston MA, Lopez AF et al. 2009 14-3-3 SHC scaffolds integrate phosphoserine and phosphotyrosine signaling to regulate PI 3-kinase activation and cell survival. Journal of Biological Chemistry. Published on February 13, 2009 as Manuscript M807637200.

Bernal-Mizrachi E, Wen W, Stahlhut S, Welling CM \& Permutt MA 2001 Islet beta cell expression of constitutively active Akt1/PKB $\alpha$ induces striking hypertrophy, hyperplasia, and hyperinsulinemia. Journal of Clinical Investigation 108 1631-1638.

Brennan L, Shine A, Hewage C, Malthouse JPG, Brindle K, McClenaghan N, Flatt PR \& Newsholme P 2002 A NMR based demonstration of substantial oxidative L-alanine metabolism and L-alanine enhanced glucose metabolism in a clonal pancreatic $\beta$-cell line - metabolism of $\mathrm{L}$-alanine is important to the regulation of insulin secretion. Diabetes 51 1714-1721.

Brennan L, Corless M, Hewage C, Malthouse JPG, McClenaghan NH, Flatt PR \& Newsholme P $2003{ }^{13} \mathrm{C}$ NMR analysis reveals a link between L-glutamine metabolism, D-glucose metabolism and gamma-glutamyl cycle activity in a clonal pancreatic beta-cell line. Diabetologia 46 1512-1521.

Cani PD, Amar J, Iglesias MA, Poggi M, Knauf C, Bastelica D, Neyrinck AM, Fava F, Tuohy KM, Chabo C et al. 2007 Metabolic endotoxemia initiates obesity and insulin resistance. Diabetes 56 1761-1772.

Chapman JC, McClenaghan NH, Cosgrove KE, Hashmi MN, Shepherd R, Giesberts AN, White S, Ammala C, Flatt PR \& Dunne MJ 1999 ATP-sensitive potassium channels and efaroxan-induced insulin release in the elctrofusion-derived BRIN-BD11 beta-cell line. Diabetes $\mathbf{4 8}$ 2349-2357.

Concannon P, Erlich HA, Julier C, Morahan G, Nerup J, Pociot F, Todd JA \& Rich SS 2005 Type 1 diabetes genetics consortium. Type 1 diabetes: evidence for susceptibility loci from four genome-wide linkage scans in 1435 multiplex families. Diabetes 54 2995-3001.

Corless M, Kiely A, McClenaghan NH, Flatt PR \& Newsholme P 2006 Glutamine regulates expression of key transcription factor, signal transduction, metabolic gene, and protein expression in a clonal pancreatic beta-cell line. Journal of Endocrinology 190 719-727.

Creely SJ, McTernan PG, Kusminski CM, Fisher M, Da Silva NF, Khanolkar M, Evans M, Harte AL \& Kumar S 2007 Lipopolysaccharide activates an innate immune system response in human adipose tissue in obesity and type 2 diabetes. American Journal of Physiology. Endocrinology and Metabolism 292 E740-E747.

Dickson LM \& Rhodes CJ 2004 Pancreatic beta-cell growth and survival in the onset of type 2 diabetes: a role for protein kinase B in the Akt? American Journal of Physiology. Endocrinology and Metabolism 287 E192-E198.

Dixon G, Nolan J, McClenaghan NH, Flatt PR \& Newsholme P 2003 A comparative study of amino acid consumption by rat islet cells and the clonal beta-cell line BRIN-BD11 - the functional significance of L-alanine. Journal of Endocrinology 179 447-454.

Drewe J, Beglinger C \& Fricker G 2001 Effect of ischemia on intestinal permeability of lipopolysaccharides. European Journal of Clinical Investigation 31 138-144.

Fiaschi-Taesch N, Stewart AF \& Garcia-Ocana A 2007 Improving islet transplantation by gene delivery of hepatocyte growth factor (HGF) and its downstream target, protein kinase $\mathrm{B}(\mathrm{PKB}) /$ Akt. Cell Biochemistry and Biophysics 48 191-199.

Hamaguchi K, Utsunomiya N, Takaki R, Yoshimatsu H \& Sakata T 2003 Cellular interaction between mouse pancreatic alpha-cell and beta-cell lines: possible contact-dependent inhibition of insulin secretion. Experimental Biology and Medicine 228 1227-1233.

Heit JJ, Apelqvist AA, Gu X, Winslow MM, Neilson JR, Crabtree GR \& Kim SK 2006 Calcineurin/NFAT signalling regulates pancreatic beta-cell growth and function. Nature 443 345-349.
Hubert FX, Voisine C, Louvet C, Heslan M \& Josien R 2004 Rat plasmacytoid dendritic cells are an abundant subset of MHC class II + CD4+CD11b-OX62- and type I IFN-producing cells that exhibit selective expression of toll-like receptors 7 and 9 and strong responsiveness to CpG. Journal of Immunology 172 7485-7494.

Jing L, Wu Q \& Wang F 2007 Glutamine induces heat-shock protein and protects against Escherichia coli lipopolysaccharide-induced vascular hyporeactivity in rats. Critical Care $11 \mathrm{R} 34$.

Kang YJ, Kusler B, Otsuka M, Hughes M, Suzuki N, Suzuki S, Yeh WC, Akira S, Han J \& Jones PP 2007 Calcineurin negatively regulates TLR-mediated activation pathways. Journal of Immunology 179 4598-4607.

Kessel A, Toubi E, Pavlotzky E, Mogilner J, Coran AG, Lurie M, Karry R \& Sukhotnik I 2008 Treatment with glutamine is associated with downregulation of toll-like receptor-4 and myeloid differentiation factor 88 expression and decrease in intestinal mucosal injury caused by lipopolysaccharide endotoxaemia in a rat. Clinical and Experimental Immunology $\mathbf{1 5 1}$ 341-347.

Kulkarni RN, Bruning JC, Winnay JN, Postic C, Magnuson MA \& Kahn CR $1999 a$ Tissue-specific knockout of the insulin receptor in pancreatic beta cells creates an insulin secretory defect similar to that in type 2 diabetes. Cell 96 329-339.

Kulkarni RN, Winnay JN, Daniels M, Bruning JC, Flier SN, Hanahan D \& Kahn CR $1999 b$ Altered function of insulin receptor substrate-1-deficient mouse islets and cultured beta-cell lines. Journal of Clinical Investigation 104 R69-R75.

Lawrence M, Shao C, Duan L, McGlynn K \& Cobb MH 2008 The protein kinases ERK1/2 and their roles in pancreatic beta cells. Acta Physiologica 192 $11-17$.

Lee JY, Ye J, Gao Z, Youn HS, Lee WH, Zhao L, Sizemore N \& Hwang DH 2003 Reciprocal modulation of toll-like receptor-4 signaling pathways involving MyD88 and phosphatidylinositol 3-kinase/AKT by saturated and polyunsaturated fatty acids. Journal of Biological Chemistry 278 37041-37051.

McClenaghan NH 2007 Functional insights for understanding and therapy of diabetes physiological regulation of the pancreatic beta-cell. Experimental Physiology 92 481-496.

McClenaghan NH \& Flatt PR 1999 Engineering cultured insulin-secreting pancreatic beta-cell lines. Journal of Molecular Medicine 77 235-243.

McClenaghan NH, Barnett CR, Ah-Sing E, Abdel-Wahab YHA, O'Harte FPM, Yoon T-W, Swanston-Flatt SK \& Flatt PR 1996a Characterization of a novel glucose-responsive insulin-secreting cell line, BRIN-DB11, produced by electrofusion. Diabetes 45 1132-1140.

McClenaghan NH, Barnett CR, O'Harte FPM \& Flatt PR $1996 b$ Mechanisms of amino acid-induced insulin secretion from the glucoseresponsive BRIN-BD11 pancreatic $\beta$-cell line. Journal of Endocrinology 15 349-357.

Newsholme P, Brennan L \& Bender K 2006 Amino acid metabolism, beta cell function and diabetes. Diabetes 55 S39-S47.

Oguri S, Motegi K, Iwakura Y \& Endo Y 2002 Primary role of interleukin-1 alpha and interleukin-1 beta in lipopolysaccharide-induced hypoglycemia in mice. Clinical and Diagnostic Laboratory Immunology 9 1307-1312.

O'Neill LA 2006 How toll-like receptors signal: what we know and what we don't know. Current Opinion in Immunology 18 3-9.

Pan DA, Lillioja S, Kriketos AD, Milner MR, Baur LA, Bogardus C, Jenkins AB \& Storlien LH 1997 Skeletal muscle triglyceride levels are inversely related to insulin action. Diabetes 46 983-988.

Podolin PL, Denny P, Lord CJ, Hill NJ, Todd JA, Peterson LB, Wicker LS \& Lyons PA 1997 Congenic mapping of the insulin-dependent diabetes (Idd) gene, Idd10, localizes two genes mediating the Idd10 effect and eliminates the candidate Fcgr1. Journal of Immunology 159 1835-1843.

Poltorak A, He X, Smirnova I, Liu MY, Van Huffel C, Du X, Birdwell D, Alejos E, Silva M, Galanos C et al. 1998 Defective LPS signaling in $\mathrm{C} 3 \mathrm{H} / \mathrm{HeJ}$ and $\mathrm{C} 57 \mathrm{BL} / 10 \mathrm{ScCr}$ mice: mutations in Tlr4 gene. Science $\mathbf{2 8 2}$ 2085-2088.

Rock FL, Hardiman G, Timans JC, Kastelein RA \& Bazan JF 1998 A family of human receptors structurally related to Drosophila Toll. PNAS 95 $588-593$ 
Sherry CL, O'Connor JC, Kramer JM \& Freund GG 2007 Augmented lipopolysaccharide-induced TNF- $\alpha$ production by peritoneal macrophages in type 2 diabetic mice is dependent on elevated glucose and requires p38 MAPK. Journal of Immunology 178 663-670.

Takamatsu N 1998 The new colorimetric assay (WST-1) for cellular growth with normal aging and Alzheimer's disease. Nippon Ronen Igakkai Zasshi 35 535-542.

Tilg H \& Moschen AR 2008 Inflammatory mechanisms in the regulation of insulin resistance. Molecular Medicine 14 222-231.

Tsukumo DM, Carvalho-Filho MA, Carvalheira JB, Prada PO, Hirabara SM, Schenka AA, Araujo EP, Vassallo J, Curi R, Velloso LA et al. 2007

Loss-of-function mutation in toll-like receptor 4 prevents diet-induced obesity and insulin resistance. Diabetes 56 1986-1998.

Tuttle RL, Gill NS, Pugh W, Lee JP, Koeberlein B, Furth EE, Polonsky KS, Naji A \& Birnbaum MJ 2001 Regulation of pancreatic beta-cell growth and survival by the serine/threonine protein kinase $\mathrm{Akt} 1 / \mathrm{PKB} \alpha$. Nature Medicine 7 1133-1137.
Vitseva OI, Tanriverdi K, Tchkonia TT, Kirkland JL, McDonnell ME, Apovian CM, Freedman J \& Gokce N 2008 Inducible toll-like receptor and $\mathrm{NF}-\kappa \mathrm{B}$ regulatory pathway expression in human adipose tissue. Obesity 16 932-937.

Vives-Pi M, Somoza N, Fernandez-Alvarez J, Vargas F, Caro P, Alba A, Gomis R, Labeta MO \& Pujol-Borrell R 2003 Evidence of expression of endotoxin receptors CD14, toll-like receptors TLR4 and TLR2 and associated molecule MD-2 and of sensitivity to endotoxin (LPS) in islet beta cells. Clinical and Experimental Immunology 133 208-218.

Received in final form 28 May 2009

Accepted 24 June 2009

Made available online as an Accepted Preprint 24 June 2009 